\title{
Stepping Stones in Scientific Writing and Publication
}

The year of 2012 is not an easy year in the history of the Journal of Dentistry Indonesia (JDI). The JDI started its first publication in 1993 under the name of Jurnal Kedokteran Gigi Universitas Indonesia. Since then, several changes in the name of the journal have been experienced; Journal of Dentistry Indonesia (JDUI) (1994-2002), Jurnal Kedokteran Gigi Indonesia (2003), Indonesian Journal of Dentistry (2004-2009) and Indonesian Journal of Dental Research (April 2010-September 2010). Last publication of the journal was the volume 17, number 2 of the year 2010 .

My appointment as the new Editor in Chief of the journal earlier this year has faced me to many challenges that are part of the responsibility of being one. Reorganization of the Editorial Board Member hopefully would bring huge changes to this journal. The new Editorial Board has decided to use the name Journal of Dentistry Indonesia with the registered ISSN 1693-9697 and committed to be consistent in our publication using that name, unless there is a very strong reason to do the other way. Therefore, the name of Journal of Dentistry Indonesia has been reused from the volume 17 number 3 of 2010.

Now, the JDI has new fresh strong-willed editorial board members who have shared the same vision to make JDI to be an international journal. By setting this vision, we are in line with the vision of the Universitas Indonesia. The vision of the Universitas Indonesia as stated in Rencana Strategis Universitas Indonesia 2007-2012 is "to become an autonomous, modern and multi-culture research university, and gain an internationally reputable academic standard" or usually heard as "Universitas Indonesia as a world class university"., However, the year of 2012 has already reached its end and how are we doing?

From a small literature search that I have done for writing this editorial, the so called "world class university" is generally referred to a great university that has characteristic of having "excellence in education of the students", "excellence in research, development and dissemination of knowledge" and "activities contributing to the cultural, scientific and civic life of society". ${ }^{3}$ Number of journal publication is one of the parameter indicating a so called world class research university. As a part of the Universitas Indonesia that need to support it to have the "excellence in dissemination of its knowledge and scientific work to contribute to the society", JDI has committed to encourage sivitas academica of UI, especially Faculty of Dentistry to publish their scientific work through scientific journal.

The Directorate General of Higher Education (DGHE) of the Republic of Indonesia through its regulation has required all university graduates (undergraduate and postgraduate) to publish their scientific work. ${ }^{4}$ Controversies have risen from that regulation, one of them is related to the quality of the resulting publication. To my opinion, there must be advantages and drawbacks in every regulation. Justification behind the making of this regulation might be caused by the fact that scientific publications from academia of all institutions in Indonesia are still lacking. The number is very low compared to our neighboring countries such as Singapore, Thailand, Malaysia and even the Philippines. Transformation is definitely needed so that Indonesia could be comparable to them.

To be established as a world class university, there are two dimensions that should be considered. ${ }^{5}$ External factors such as "the role of government at national and provincial levels; and resources to improve prominence of the university" and "internal factors that are strongly related to the individuals in the institutions". These factors need strategic steps to transform these individuals as part of a world class university.

"Are we ready to transform ourselves to become part of a world class university?" If this question was asked to me, my answer would be "I definitely need a multistep process to do that. Since my part in UI would be measured by how many published articles that could make impact to the world." I should confess that my writing experience is still very limited. Although the major reason would in me, but I thought the atmosphere of doing scientific article writing has not adequately given in the university teaching. Therefore, it might be controversial that I actually support the DGHE regulation about the compulsory scientific article writing publication on scientific journals by all graduate students. It might be right that the quality of publication by undergraduate students is compromised, but the experience of doing that writing would be very valuable for the future; to the students and Indonesia. It would also be true for postgraduate students who have not had any experiences of publishing their scientific work. These would increase demand to publish the scientific articles, therefore more journals would be needed or no more journals would have starved of articles for publication. Of course it is the responsibility of the 
authors and the editors to keep the writing appropriate for scientific publication. I would call this, a stepping stone of writing a high quality scientific article.

It would be true as well for the JDI, to be qualified as an international journal, we have stepping stones that need to be passed. While increasing the quality of scientific writing by holding article writing workshops and inviting nation-wide and worldwide potential authors, JDI also commits to increase the quality of its editors and reviewers by self motivate ourselves as editors; to be good journal editors, by attending workshops for editors, and inviting international peer reviewers. We are now developing our own webpage that is http:// www.jdentistry.ui.ac.id and JDI proudly announces its accessibility and visibility in Google Scholar and soon to be in the Directory of Open Access Journal (DOAJ) database. Furthermore, aiming for Scopus and PubMed indexing, which are two reputable scientific databases. By the time JDI is indexed in Scopus and/or PubMed, it could be considered as an international journal, as categorized by DGHE. ${ }^{6}$

In this number, JDI also declares its first publication in collaboration with the Indonesian Dental Association. Both organizations belief that the collaboration would definitely increase number of readers in dentistry and its related community throught the nation, therefore ensuring knowledge dissemination and transfers. Meanwhile, JDI editors are seriously preparing ourselves to get national accreditation from DGHE by 2013 and becoming the most reliable source of information on current development in all sciences relevant to dentistry in Indonesia.

Transformation would not happen instantly, it is an evolution process accompanied by strong determination, that could be started from ourselves. Culture of writing and doing it happily would be a firm first stepping stone for us.

\section{REFERENCES}

1. Rencana Strategis Universitas Indonesia 20072012. Membangun masa depan yang lebih baik melalui peningkatan keunggulan Universitas Indonesia [Internet]. Available from http://www. ui.ac.id/download/renstra_ui.pdf. Indonesian.

2. Sudibyo B. 50 universitas disiapkan jadi "World Class University" [Internet]. [updated 2007 Sep 4; cited 2012 Oct 14]. Available from http:// www.antaranews.com/berita/1188900543/50universitas-disiapkan-jadi-world-class-university. Indonesian.

3. Levin HM, Jeong DW, Ou D. What is a world class university? [Internet]. [cited Oct 14, 2012]. Available from:http://www.tc.columbia.edu/ centers/coce/pdf_files/c12.pdf.

4. Santoso D. Publikasi karya ilmiah. Kemdikbud Ditjen Dikti, Letter no. 152/E/T/2012. [Internet]. [updated 2012 Jan; cited 2012 Oct 14]. Available from: http://dikti.go.id/attachments/article/2670/ Surat\%20Publikasi\%20Karya\%20Ilmiah.pdf. Indonesian.

5. Jamil S. The Challenge of establishing world-class universities. The World Bank. 2009[Internet]. [cited 2012 Oct 14]. Available from http:/ siteresources.worldbank.org/EDUCATION Resources/2782001099079877269/547664 1099079956815/547670-1237305262556/WCU. pdf.

6. Jurnal Indonesia bertaraf Internasional sesuai kategori Dikti [Internet]. [cited 2012 Oct 11]. Available from: http://www.dikti.go.id Archive2007/p3m/files/akreditasi_jurnal?KJI doc. Indonesian.

\section{Yuniardini Septorini Wimardhani}

Editor in Chief Journal of Dentistry Indonesia 